\title{
Study on the Opportunities and Countermeasures of Jilin Province in the Sino-Korean FTA Development
}

\author{
Shiyan $\mathrm{Bai}^{1, \mathrm{a}}$ and Hongwei $\mathrm{Su}^{2, \mathrm{~b}}$ \\ ${ }^{1}$ College of Humanities and Sciences of Northeast Normal University, Changchun, \\ Jilin Province 130117, China \\ 2 Jilin University, Changchun, Jilin Province 130000, China \\ a 445996074@qq.com, ${ }^{\mathrm{b}}$ 409577882@qq.com
}

\section{Keywords: Sino-Korea FTA; Jilin Province; Countermeasures}

\begin{abstract}
China and South Korea are core countries of Northeast Asia. Since the two countries established diplomatic relations, their economic and trade relationship is on good terms. The background of establishing Sino-Korea FTA, the evolution of Sino-Korea Trade, current foreign trade situation in Jilin Province and the necessity of Jilin Province participating in building Sino-Korea FTA were discussed. In conclusion, the countermeasures were proposed in this paper to promote Sino-Korea FTA by applying strengths of Jilin provinces.
\end{abstract}

\section{Introduction}

With the broad development of economic cooperation among countries and rapid development of regional economic integration, many countries have participated in multilateral or bilateral cooperation on regional economy for the sake of securing domestic benefits and development. Building FTA has been one of the important forms for many countries participating in regional economic integration. China and South Korea are core countries of Northeast Asia. Since the two countries has established diplomatic relations, their economic and trade relationship is on good terms and they have become important economic partner for each other. Blessing with complementary resource endowment, market and technology and industrial structure, geographical proximity and common historic culture, China and South Korea have developed to build Sino-Korea FTA. The building of Sino-Korea FTA will be certain to boost their economic development, improve their economic and welfare level and exert far-reaching impact upon economic cooperation and prosperity of them or even the entire East Asia.

\section{Basic Situation}

After a decade of negotiation for building of Sino-Korea FTA, China and South Korea has completed all of the negotiations in February 2015. In November 2004, Chiefs of the PRC and South Korea had reached to a consensus on concluding Sino-Korea FTA during APEC and declared that folk study on Sino-Korea FTA launched. At the very beginning of 2007, university-industry-government feasibility research on Sino-Korea FTA launched. Five rounds of university-industry-government research conference between the PRC and South Korea had been hold, in which notes of topics on rules of origin, trade remedy measures, agriculture, fishing \& Forestry, service trade, investment, competition policy, intellectual property and government procurement had been compared in depth. In May 2012, intergovernmental negotiation of Sino-Korea FTA launched. The consensuses included liberalization level of trade in goods, scope of agreement and principles of negotiation in different areas, framework and content element etc. In November 2014, Chiefs of the PRC and South Korea had met in Beijing, and both sides confirmed that substantive negotiations for Sino-Korea FTA had finished. So far the Sino-Korea FTA is the free trade area that covers the widest ranges among foreign negotiations and involves the highest value of trade in state level. In terms of the level of open, agreement covers 17 areas, such as trade in goods, trade in service, investment and rules. 


\section{Evolution of Sino-Korea Trade and Current Foreign Trade Status of Jilin Province}

Based on analysis on trade amount and structure of China and South Korea(see table 1 and table 2), several basic conclusions could be drawn. First, China has trade deficit with South Korea, while South Korea has trade surplus with China. Second, in terms of trade structure between China and South Korea, the proportion of secondary/high-technology goods has increased, while the proportion of simple-to-manufacture products and low-technology goods has decreased year by year. Third, in terms of proportion of specific goods between China and South Korea, the export concentration of China to South Korea is obviously higher than that of South Korea to China, which means that Chinese export merchants would face with tough competition.

Table 1 Change of China's Trade with South Korea (one hundred million US dollar)

\begin{tabular}{llllllll}
\hline Year & Import & Export & Total trade & $\begin{array}{l}\text { Trade } \\
\text { balance }\end{array}$ & $\begin{array}{l}\text { Proportion } \\
\text { of Import }\end{array}$ & $\begin{array}{l}\text { Proportion } \\
\text { of Export }\end{array}$ & $\begin{array}{l}\text { Proportion } \\
\text { of } \\
\text { trade }\end{array}$ \\
\hline 2000 & 232.07 & 112.92 & 345.00 & -119.15 & $10.31 \%$ & $4.53 \%$ & $7.27 \%$ \\
2001 & 233.77 & 125.19 & 358.96 & -108.58 & $9.60 \%$ & $4.70 \%$ & $7.04 \%$ \\
2002 & 285.68 & 155.35 & 441.03 & -130.33 & $9.68 \%$ & $4.77 \%$ & $7.10 \%$ \\
2003 & 431.28 & 200.95 & 632.23 & -230.33 & $10.45 \%$ & $4.59 \%$ & $7.43 \%$ \\
2004 & 62.34 & 278.12 & 900.46 & -344.23 & $11.09 \%$ & $4.69 \%$ & $7.80 \%$ \\
2005 & 768.20 & 351.08 & 1119.28 & -417.13 & $11.64 \%$ & $4.61 \%$ & $7.87 \%$ \\
2006 & 897.24 & 445.22 & 1342.46 & -452.02 & $11.34 \%$ & $4.59 \%$ & $7.63 \%$ \\
2007 & 1037.52 & 564.32 & 1601.84 & -473.20 & $10.85 \%$ & $4.63 \%$ & $7.36 \%$ \\
2008 & 1121.38 & 739.32 & 1860.70 & -382.06 & $9.90 \%$ & $5.17 \%$ & $7.26 \%$ \\
2009 & 1025.52 & 536.80 & 1562.32 & -488.72 & $10.20 \%$ & $4.47 \%$ & $7.08 \%$ \\
2010 & 1383.39 & 687.66 & 2071.06 & -695.73 & $9.91 \%$ & $4.36 \%$ & $6.96 \%$ \\
2011 & 1627.17 & 829.20 & 2456.37 & -797.97 & $9.33 \%$ & $4.37 \%$ & $6.74 \%$ \\
2012 & 1687.28 & 876.74 & 2564.02 & -810.55 & $9.28 \%$ & $4.28 \%$ & $6.63 \%$ \\
2013 & 1830.73 & 911.65 & 2742.38 & -919.08 & $9.39 \%$ & $4.13 \%$ & $6.59 \%$ \\
2014 & 1901.05 & 1003.35 & 2904.40 & -897.71 & $9.71 \%$ & $4.28 \%$ & $6.75 \%$ \\
\hline Growth & $719.16 \%$ & $788.52 \%$ & $741.86 \%$ & & & &
\end{tabular}

Table 2 Import Trade Structure of China with South Korea (one hundred million US dollar)

\begin{tabular}{lllllllll}
\hline \multicolumn{3}{c}{ Absolute Value } & \multicolumn{3}{c}{ Proportion in Import } \\
\hline & $\begin{array}{l}\text { Resource- Low } \\
\text { based }\end{array}$ & $\begin{array}{l}\text { Secondary- } \\
\text { tech }\end{array}$ & tech & High-tech & $\begin{array}{l}\text { Resource- Low- } \\
\text { based } \\
\text { tech }\end{array}$ & $\begin{array}{l}\text { Secondary- } \\
\text { tech }\end{array}$ & $\begin{array}{l}\text { High- } \\
\text { tech }\end{array}$ \\
\hline 2000 & 44.72 & 51.16 & 73.56 & 54.07 & $13.35 \%$ & $18.67 \%$ & $10.94 \%$ & $8.62 \%$ \\
2005 & 86.68 & 91.50 & 200.77 & 368.60 & $8.80 \%$ & $15.47 \%$ & $11.73 \%$ & $15.65 \%$ \\
2010 & 163.34 & 97.08 & 390.53 & 692.28 & $6.06 \%$ & $13.10 \%$ & $11.34 \%$ & $16.57 \%$ \\
2013 & 282.00 & 102.94 & 466.37 & 940.98 & $7.51 \%$ & $12.04 \%$ & $11.70 \%$ & $16.75 \%$ \\
\hline $\begin{array}{l}\text { Growth } \\
\text { Rate }\end{array}$ & $530.61 \%$ & $101.24 \%$ & $533.97 \%$ & $1640.45 \%$ & & & & \\
\hline
\end{tabular}

The growth of foreign trade in Jilin Province is basically identical with its GDP growth rate, but both have been affected by international trade environments. First, since China became a WTO member and introduced the policy of revitalizing the old industrial bases in Northeast region in 2003, its GDP has achieved big growth, and foreign trade has developed rapidly at the speed of $66.7 \%$. Hence, the policy had a great influence on economic development in Jilin Province. Afterwards, its GDP fell back and foreign trade was caught in faltering growth, which showed that Jilin province had failed to make considerable progress and development by seizing the preferential opportunity. Second, the import amount of Jilin Province was higher that export amount all the same since 2003, which showed that Jilin Province had a trade deficit in foreign trade. Third, Jilin Province had had a slow growing in trade deficit from 2003 to 2008. Since the Global Economic 
Crisis broke out in 2008, the export amount of Jilin Province in 2009 declined sharply, but its import amount remained uninfluenced. After 2009, the export amount of Jilin province slowly returned to previous level, while its import amount increased greatly, therefore its trade deficit increased further. Last but not least, during the world economic crisis in 2009, the GDP in Jilin province still remained in higher level, but its import and export amount was sluggish and on the decline.

\section{The Necessity of Jilin Province Participating in Building of Sino-Korea FTA}

New Growth Pole Needed for Economic Development in Jilin Province The regional economic growth pattern in China has been featured with that the growth rate of East Region has tended to be stable, the growth rate of Central and Western regions increases and in contrast the growth rate of Northeast Region decreases greatly, therefore new growth pole is needed for economic development in Jilin Province. In order to solve the current slowdown in the process of economic development in Jilin Province, we have to innovate thinking. Jilin province has devoted to developing the modern service industry and adjusting industrial structure for three times, and has determined to make mainstay industry bigger and stronger. Moreover, it has hammered at high-end manufacturing by integrating rich natural resources in surrounding countries and transferring them into high value-added products. Owing to location factor, natural endowments and historical reasons, Jilin Province has formed automobile industry, petrifaction, agricultural products processing industry, metallurgic industry etc. In order to further improve economic development level of Jilin Province, its central position advantages in regional economic cooperation of Northeast Asia have to be exploited to the full. On the basis of economic development level, geographic position, existing industrial structure, external passageway construction and foreign trade of Jilin Province, it is a new platform to develop economic and trade contact with Russian Far-East, Mongolia, South Korea and North Korea by improving its economic cooperation with those countries.

New Acting Point is needed in Upgrading Industries in Jilin Province. In order to strengthen endogenous development force of economy in Jilin Province and revive the economic vitality of old industrial bases, Jilin Province has transformed traditional industries and developed green energy industries, as well as carried out the mainstay industry zooming plan. In 2013, being affected by insufficient market demand, frequent-occurring industrial accidents and earthquakes, industrial economy declined increasingly. In addition, the added value and growth rate of industrial enterprises above designated size in the latter half of the year increased in one digit for five months in a row. Under this condition, Jilin Province has to take advantage of resources and passageway brought by cooperating with South Korea in fields of economy and technology and speed up the construction of specialty industry so as to improve the competitiveness of whole value chain by virtue of industrial upgrading, besides further improving the supporting role of mainstay industries, such as automobile industry, food industry and pharmaceutical industry.

Beneficial to Jilin Province Regional Cooperation with Northeast Asia and Promoting its Open Economy. The trade and economic links between Jilin Province and Northeast Asian nations have been strengthened greatly in recent years. Northeast Asian nations have played an important role in foreign trade of Jilin Province. However, regional economic cooperation with Northeast Asian region is moving slowly and uncertain. It has been key for Jilin Province to formulate open economy strategy. In terms of the geoeconomics pattern of Northeast Asia, Jilin province is in key position; in terms of the economic technology level, it is at middle level. As the old industrial base of China, Jilin Province has recently made great achievements in SOE reform, especially in areas of petrifaction, equipment manufacturing and agriculture, which have provided sound foundation for Jilin province participating in economic cooperation with the entire Northeast Asian region. Moreover, the gradient difference of economic and technological development level between China and South Korea is conducive to the movement of production factors. As the front edge of Sino-Korea FTA, the border cities of Jilin province, such as Huichun, Helong and Changbai are complementary with South Korea in structure of resource factors and economic technology. Hence, the potential Jilin-Korean economic cooperation is enormous, which is conductive to 
consolidate China's strategic place in regional economic co-operation with Northeast Asia.

\section{Recommendations for Jilin Province Participating in Building Sino-Korean FTA}

\section{International Trade Companies Would Improve its Core Competitiveness by Virtue of Sino}

-Korean FTA. First, FTA has offer the opportunity to foreign trade liberalization and integration of domestic and foreign trade. By constructing an international business environment and establishing market-oriented, legalized and forging world-oriented free trade base, it has formed a network of free trade, which covers tremendous trading limit and market size. Hence, it will certainly provide a handsome prospect for middle and small-sized enterprises, which have served as fresh troops in foreign trade development. More importantly, it has provided a chance for enterprises in optimizing and upgrading their industry chain, value chain, supply chain and service chain.

Employ Multiple Foreign Trade Strategies in Terms of Different Conditions, and do not Blindly Introduce Foreign Capital. As for the developing counties and towns, it is supposed to adopt encouragement policies for exporting primary commodity. Moreover, it is also available to employ the processing trade, because primary commodity belongs to the industry of resource-intensive and labor-intensive that could be a way to deal with the employment. As the old industrial base, Jilin province is with certain foundation as well as being backward in industrial development, therefore related industries can be replaced by import. We have to create a more loose and freer environment for both competitive industries and inferior industries, such as grain, apparel and auxiliary product and textile, which are enabled to avoid persecution and retaliation imposed other countries in foreign trade strategy. As for the high and new technology industry, such as backward electronic industry, Jilin Province is devoted to give energetic support to attract foreign businesses and investment and introduce advanced foreign technology, capital and advanced managerial experience, so as to improve the competitiveness of export products. However, it has disadvantages, which are that the export industry is hard to form a system and subject to foreign merchants. Hence, Technology Spillover Effect generated by foreign-owned enterprise shall be paid attention to, and encouraging export and domestic production shall be carried out simultaneously.

Improve Foreign Trade Levle and Dependence and then Strive for Being a Developed Foreign Trade Province. The developmental level of foreign trade in Jilin Province is very backward, and its dependence degree of foreign trade is only $14.36 \%$, which is significantly different from the national average level. Moreover, its export trade dependence degree has even lowered than $4.4 \%$, therefore it is baldly in need of expanding foreign trade scale, improving foreign trade dependence degree at provincial level, increasing export of competitive industry, speeding up trade development of other industries and participating in world competition to the full. In order to strive for NO. 1, the government has to seize the opportunity of industrial transfer and take advantage of public preferential policy, and plaid a part in guidance to the full. The government has plaid a pivotal role in both the development of foreign trade of foreign trade and domestic foreign trade. Meanwhile, opportunity is of equal importance.

Establishing Jilin-Korean Free-Trade Zone In August 2013, the State Council approved the establishment of SFTZ. The plan of Shanghai FTZ is aimed to carry out open policy in areas of finance, trade and shipping and seek innovation of aspect of management, taxation and laws and regulations. The Sino-Korea FTA is available to follow the example of SFTZ and try to establish Pilot Free Trade Zone with South Korea and construct International(Northeast Asia) Free Trade Area.

Urban Strategy of Sino-Korea Free-trade Zone in Jilin Province Changchun is the bridge tower of free trade zone of Northeast Asia. Lying in the center of the Songliao Plain, Changchun is the natural geographic center of Northeast Region, the geometric center of Northeast Asia and core of cross-shaped economic corridor of Northeast Asia. As the is the capital and largest city of Jilin Province, Changchun the core district of leading region of development and opening of Changchun-Jilin-Tumen. Hunchun is a county-level city in the Yanbian Korean Autonomous Prefecture, far eastern Jilin province, Northeast China. It borders North Korea (North Hamgyong province) and Russia (Primorsky Krai), which is also known as the Golden Delta of Northeast Asia. 
It is the outpost position of exploiting Northeast Asia market and Central Asia market, as well as the starting point of Northeast Silk Road of Korean Peninsula-China-Russia-Central Asia. Serving as the International Logistics Center of Northeast Asia, it offers superior geographical condition for realizing free trade between the PRC and South Korea.

Sino-Korea Industries Cooperation Strategy By industry cooperation between the PRC and South Korea, supports from MOTIE and other Korean governmental agencies can be gained. Hence, it is available to acquire Korean IT fusion technique from various industry associations and large-scale resources from Hyundai Motor and POSCO etc. Jilin province is enabled to cooperate with South Korea in areas of agriculture, IT technology, motor and steel, energy, production and processing, physical distribution and tourism.

Strategy of Hardware and Software infrastructure construction Port infrastructure construction, highway and railway infrastructure construction are available to provide hardware support for FTA. Meanwhile, software infrastructure could be constructed by virtue of strengthening communication and cooperation between universities in China and South Korea, setting up course of bridge talent training, training professionals devotedly who have a good command of Chinese and Korean and familiar with Chinese and Korea cultures, cultivating indispensable international talents for various industries. Above all, it is enabled to ease talent crisis in China and South Korea and improve industry cooperation and mutual economic development of China and South Korea.

\section{Summary}

The objective of this paper is to analyze the opportunities and challenges to Jilin Province taken by the establishment of Sino-Korea FTA. Firstly, the background situation of stabling Sino-Korean FTA was introduced. In order to analyze the historical evolution of Sino-Korean trade and current Foreign Trade Status of Jilin Province, the changes and trade structure of China with South Korea were analyzed. Moreover, the necessity of Jilin Province participating in building of Sino-Korea FTA was researched. In conclusion, some recommendations were given for Jilin province so that it may apply its strengths to promote its developing FTA with South Korean.

\section{Acknowledgments}

The paper is the achievements of the " $13^{\text {th }}$ Five" Social Science Fund of the Education Department of Jilin Province, with contract number of JJKH20170980SK .

\section{References}

[1] Zhang Wen,Sino-Korea FTA will go into effect at the end of the year launching a big market of $\$ 12$ trillions, J of Finance Economy, 2015, No 23, p7.

[2] Wang Huanhuan, Zhou Kang, Study on the Influential Factor and Potential of China Agricultural Products Export to South Korea_-Based on Gravity Model, J of Economic Research Guide, 2015, No 22, p188-190.

[3] Su Yi, Li Hui, SWOT analysis on Sino-Korea FTA, J of Cooperative Economy \& Science, 2016, No 4, p116-117.

[4] Li Zheng, Early Implementation at the Field of Sino-Korea FTA, J of China Sate Finance, 2015, No 22, p21-23.

[5] Wu Keliang, Building of Sino-Korea FTA and its Effect upon Cooperation between Jilin Province and South Korea, J of Contemporary Korea, 2015, No 3, p44-63.

[6] Liu Yizhuo, $\mathrm{Li} \mathrm{Ou}$ and $\mathrm{Xu}$ Ruili, the Impact upon Chinese Agriculture of Establishing Sino-Korea FTA, J of Yunnan University of Finance and Economics, 2015, No 6, p154-160.

[7] Zhao Liang, Chen Shumei, FTA-driven_-Based on the Comparative Study of Sino-Korea FTA, Sino-Japan FTA and RCEP, J of Economic Review, 2015, N o 1, p92-102.

[8] Chen Cheng, Lu Ning, the impact upon Chinese Steel Import and Export of Sino-Korea FTA, J 
of Metallurgical Economics and Management, 2015No 2, p17-18.

[9] Tang Jing, Future Trend of Sino-Korea FTA: Resolve Plight and Develop Future, J of International Economic Cooperation, 2015, No 4, p12-15.

[10] Substantial Progress Made by Sino-Korea FTA, J of Landbridge Horizon, 2015, No 2, p24-25. 